\title{
The Role of Supplementary Services in Enhancing Customer-Based Brand Equity: An Applied Study on Five Star Hotels in Cairo City
}

\author{
Prof. Dr. Wageeh Nafei \\ Professor of Human Resources Management \\ Chairman of Business Administration Department \\ Faculty of Commerce - University of Sadat City
}

Wessam Hemdan Ahmed EL-Horany

Demonstrator in Business Administration Department

Faculty of Commerce - University of Sadat City

2021

المجلة العلمية للاراسات والبحوث المالية والإدارية المجلد التاسع العدد الأول يونيه 2021 - 573 - 


\begin{abstract}
This research focused on understanding the important of Supplementary Services (SS) and its role in enhancing Customer-Based Brand Equity (CBBE) in Five-stars Hotels in Cairo city in Egypt. In order to achieve this, the research dealt with the concepts of SS, its dimensions and $\mathrm{CBBE}$ concepts and its dimensions. The field study dealt with the role of SS in enhancing and improving CBBE by preparing a survey list and distributing it to 384 customers who benefit from the services provided in the five-star hotels in Cairo using the sample method due to the large size of the population where the received and correct lists reached 300 survey lists and survey responses were $78 \%$. The statistical analysis was carried out by means of a number of statistical methods and tests, such as the confirmatory factor analysis method, multiple regression and correlation analysis and one-way ANOVA method.

The research reached to a number of results the most important of them is there is a positive statistically significant relationship between the dimensions of SS (information, order taking, billing, payment, consultation, hospitality, safe keeping and exception) and CBBE. In light of the results of the research, it was possible to reach a set of recommendations, the most important of which are, (1) the need for officials in the five-star hotels under study to provide SS that valueenhancing services such as (hospitality consultation - exception), (2) the need for attention of those responsible for the hotel's brand image, preservation of its history and reputation, and attention to everything that makes the hotel's image appropriate. However, the scope of this study, the methods used in it, and its findings indicate that there are areas for further future studies.
\end{abstract}

Keywords: Supplementary Services, Customer-Based Brand Equity, Brand Awareness, Brand Image, Brand Loyalty, Hospitality.

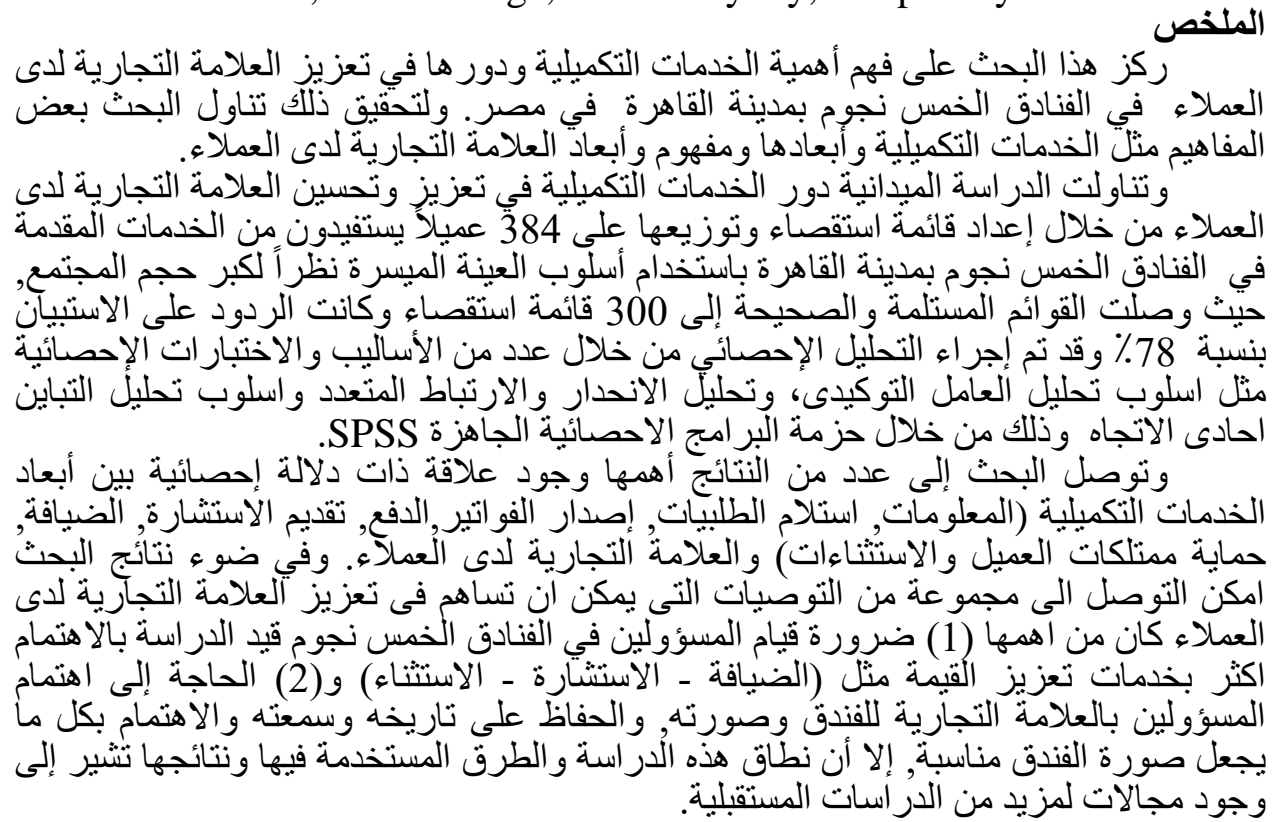

المجلة العلمية للاراسات والبحوث المالية والإدارية المجلد التاسع العدد الأول يونيه 2021 - 574 - 


\section{Introduction}

Service and service quality are getting to be the most important issues in the institutions and organizations that present services to their customers notwithstanding of their introduction and field of intrigued. By and large talking, the services appear as center services which are the essential advantage that a customer gets from obtaining a certain item/service and SS which are the non-routine services that take after the method of procuring the item/service. Through the literature, there showed up an intrigued in caring for the level of center services at the expense of SS (Hashem, 2018).

A service item comprises two elements, the core product, and Supplementary Services (SS). The core product is based on the group of benefits and arrangements delivered to customers. Surrounding the core product may be an assortment of service-related activities called SS. SS increase the core product by encouraging it to utilize and upgrading its esteem and offer. The SS regularly play an imperative part in separating and situating the core product against competing services (Lovelock, et al., 2016).

Customer based Brand Equity (CBBE) is one of the top issues in the tourism industry (Im \& Han, 2012) and hotel context (Šeric, et al., 2017).

Brand equity is a concept born in 1980s. It has aroused intense interest among business strategists from a wide variety of industries as brand equity is closely related with brand loyalty and brand extensions. Besides, successful brands provide competitive advantages that are critical to the success of companies (Chieng \& Goi, 2018).

The purpose of this study is to focus on understanding the important of SS which offered to the customers who benefit from the services of the five star hotels in Cairo city in Egypt. So, this research aims at studying the impact of SS on CBBE.

\section{Research Terminologies}

\subsection{Supplementary Services}

There are two types of supplementary services: those that facilitate supplementary services and those that enhance supplementary services. Information, order-taking, billing, and payment are examples of Facilitating supplementary services that make life easier. These components are needed for the delivery of services and aid in the use of the core product (Hashem, 2018).

SS are classified as "facilitating products," which are "services or goods that must be present for the consumer to use the core product," and "supporting products," which are "additional products" that "add value to the core product." These ancillary goods can assist in differentiating the own service from that of competitors (Kotler, et al., 2017).

المجلة العلمية للاراسات والبحوث المالية والإدارية المجلد التاسع العدد الأول يونيه 2021 - 575 - 
SS are synergistic, helping to distinguish a business from its rivals while also providing sources of competitive advantage (Tarabieh, \& Siron, 2015).

Based on what has been mentioned previously, the researcher suggests that SS can be defined as: The services that complement the core service that provided to the customer. Also the researcher is adopting this concept "SS are enhancing the core product, facilitating its utilization and enhancing its worth.

\subsection{Customer-Based Brand Equity}

Brand equity is an idea brought into the world during the 1980s. It has stirred extreme premium among business planners from a wide assortment of enterprises as brand value is firmly identified with brand devotion and brand augmentations. Plus, fruitful brands give upper hands that are basic to the achievement of organizations (Chieng \& Goi, 2018).

CBBE is conceived from the point of view of a single consumer. When a customer is familiar with a brand and has positive, solid, and distinct brand associations in their mind, CBBE occurs (Kotsi, et al., 2018).

Once the consumer identifies a brand; he/she will assign a meaning to the brand and build associations. Brand awareness stimuluses the formation of such associations, and therefore, it is to be expected that a greater awareness of a hotel will enhance the perception of its brand equity. Brand awareness may increase brand equity over time (Harrington, et al., 2017).

Based on what has been mentioned previously, the researcher adopted this definition: "a set of perceptions, attitudes, knowledge, and behaviors on the part of consumers... that allows a brand to earn greater volume or greater margins than it could without the brand name.

\section{Literature Review}

\subsection{Supplementary Services}

Hashem (2018) wanted to know how the SS 'flower of service' dimensions influenced customer satisfaction in Jordan's private hospitals. The aim of the study was to determine the level of SS in private hospitals in Jordan, as well as how the definition of supplementary service can affect customer satisfaction, given that the 'core service' is typically what draws patients to hospitals. The study's findings revealed that the 'flower of service' dimensions have an effect on customer satisfaction (Information, Order Taking, Consultation, Hospitality, Billing, and Payment) except (Exception, Safe Keeping).

Martins \& Patrício (2018) contributed to a better understanding of the antecedents and consequences of supplementary services and loyalty to consumer networks hosted by companies in the scope of social networking sites (SNS). Results show that all six identified performance dimensions significantly impact CSN loyalty. However, while selfexpressiveness, communication and rewarding activity (which are closely

المجلة العلمية للاراسات والبحوث المالية والإدارية المجلد التاسع العدد الأول يونيه 2021 - 576 - 
related to social and hedonic value) are predictors of loyalty to the CSN, These results reveal the dichotomous nature of CSNs, as communities of people with shared interests and supplementary services created by companies to add value to their core offering.

\subsection{Customer -Based Brand Equity}

Bose, et al. (2020) aimed to contribute theoretically by exploring and improving the dimensions and instrument of customer based place brand equity (CBBE) quantitatively, the study employed: discussion in focus groups, in-depth interviews, and a survey in order to establish and validate the CBPBE measurement objects On a total sample of 437 respondents, confirmatory factor analysis generated a nine-item CBPBE scale, which reflected multidimensional constructs such as place brand salience, perceived quality, and place brand engagement.

Veloutsou, et al. (2020) The CBBE deconstruction and reconstruction process for consumers' unfavorable brands. Self-brand relationship and partner quality are identified as the main links for the deconstruction and reconstruction of $\mathrm{CBBE}$, respectively, after analyzing related customer survey data using fuzzy set qualitative comparative analysis. The paper comes to a close with a review of the theoretical aspects. The paper ends with a summary of the theoretical and managerial consequences of the results and directions for future research.

Sürücü et al. (2019) investigated the effect of Customer-Based Brand Equity (CBBE) on customer loyalty and further examines the mediatory roles of customer satisfaction and trust in the hotel industry. To accomplish this goal, a questionnaire was developed and data was collected from 918 hotel guests of 39 five-star hotels in 10 cities in Turkey. According to the findings in order to increase customer loyalty, hotels should improve customer satisfaction, create confidence, and grow CBBE. There is a discussion of both theoretical and practical implications.

\subsection{The Relationships between $\mathrm{SS}$ and $\mathrm{CBBE}$}

Kheiry (2019) investigated the impact of the marketing mix (price, product, place, promotion) and after-sales services on three dimensions of brand equity (perceived quality, brand loyalty, and brand awareness).After-sales service in the automotive industry is emphasized as a key and effective element using the Aaker Model, in the promotion of brand loyalty, brand equity, and even product pricing According to the findings, product, position (distribution), promotion (advertising), and after-sales services all have a major effect on brand equity dimensions.

Amin (2014) attempted to devise a strategy. Supplementary and basic services to Egyptian higher management education institutions (faculties of commerce), assisting in the branding of these institutions in Arab world markets, Supplementary services, according to this paper add value to core services, gives companies a competitive advantages over their competitors. Based on the findings of this study, companies in the travel and tourism industry, especially convention centers, may want to

المجلة العلمية للاراسات والبحوث المالية والإدارية المجلد التاسع العدد الأول يونيه 2021 - 577 - 
consider offering supplementary services to their customers, such as greeters.

\section{The Research Gap}

1. The current study deals with the role of SS and their effect on CBBE in the five-star hotels in Cairo, which confirms the fundamental difference of this study from previous studies.

2. This study seeks to confirm or differ from some of the conclusions reached - previous studies that focused on studying the relationship between SS and CBBE; this helps the hotels under study to benefit from the results of this study in increasing the provision of SS to their customers and improving brand equity among customers.

3. There is a scarcity of studies that discussed the relationship between the $\mathrm{SS}$ and $\mathrm{CBBE}$ especially in the Arabic region. Therefore, there is no empirical research - according to the researcher knowledge, discussed the relationship between SS with its eight dimensions (information, order taking, billing, payment, consultation, hospitality, safe keeping and exception).and CBBE with its four dimensions (brand awareness, brand image, perceived quality, brand loyalty).

4. The current study agreed with the previous studies that are available to the researcher related to SS and CBBE on the method of investigation as a way of collecting field data and information, while it differed in the statistical tools and methods used.

\section{Research Problem \& Questions}

The researcher reached to the research problem through two sources. The first is the previous studies that dealt with the relationship between SS and CBBE. In light of previous studies related to SS and its effect on other variables, there is a study (khairy, 2019) showed that the effect of aftersales services on three dimensions of brand equity (perceived quality, brand loyalty, and brand awareness). This called for the researcher to test this relationship in the five stars hotels in Cairo city. The second is the pilot study, which was conducted in an interview with (51) customers who benefit from the services of the five stars hotels in Cairo city.

From this standpoint, the current study comes to confirm the interest in this topic in the Arab and Egyptian environment in order to fill some of the lack of knowledge and to add a new round of research seminars in continuity with the research efforts that address this important vital area and then the problem of the study can be summarized in an attempt to answer the following questions:

1. What is the statistically significant relationship between SS (information, order taking, consultation, hospitality, safe keeping, exception, billing, and payment) and $\mathrm{CBBE}$ in the five star hotels in Cairo city?

2. Is there a significant difference between customers' opinions about SS in five star hotels in Cairo city, according to different demographic variables (gender, marital status)?

المجلة العلمية للاراسات والبحوث المالية والإدارية المجلد التاسع العدد الأول يونيه 2021 - 578 - 
3. Is there a significant difference between customers' opinions about CBBE in five star hotels in Cairo city, according to different demographic variables (gender, marital status)?

\section{Research Objectives}

The Study seeks to achieve the following Objectives:

1. To examine the effect of SS (information, order taking, consultation, hospitality, safe keeping, exception, billing, and payment) on CBBE in five star hotels in Cairo city.

2. Determine the extent of difference between customers' opinions about SS in five star hotels in Cairo city, according to different demographic variables (gender, marital status).

3. Determine the extent of difference between customers' opinions about CBBE in five star hotels in Cairo city, according to different demographic variables (gender, marital status).

\section{Research Hypotheses}

In order to achieve the study objectives, we propose the following hypotheses which are formed depending on the literatures related to the research topic, individual interviews, and observation during the Pilot study. The following hypotheses were developed to test if there is a significant correlation between SS and CBBE.

H1: Supplementary Services (information, order taking, consultation, hospitality, safe keeping, exception, billing, and payment) has no significant effect on CBBE in five star hotels in Cairo city.

H2: There is no significant difference between customers' opinions about SS in the five-star hotels in Cairo city, according to different demographic variables (gender, marital status).

H3: There is no significant difference between customers' opinions about CBBE in the five-star hotels in Cairo city, according to different demographic variables (gender, marital status).

\section{Research Importance}

The importance of this study is derived from the following factors:

1. This research is considered as a complementary attempt to other attempts made in the field of services (marketing), in the business sector in general and the hotel sector in particular, which focused on analyzing the level of SS and their impact on CBBE in the five-star hotels in Cairo.

2. The research tries to shed light on the concept and dimensions of SS and CBBE in the five-star hotels in Cairo, and a simple scientific addition to the existing studies, and hence, this research is theoretically important.

3. The importance of the current study stems from the relative importance of the tourism and hotel sector in Cairo, as it is considered one of the cities that belong to one of the most important regions at the level of the Arab republic of Egypt. Rather, it must also be viewed from the perspective that it is provided in an area considered to be the focus of

المجلة العلمية للاراسات والبحوث المالية والإدارية المجلد التاسع العدد الأول يونيه 2021 - 579 - 
attention of the Arab world, and therefore supplementary residency services in the city of Cairo must be linked to this unparalleled position.

\section{Research Limitations}

1. The population of the study included the five star hotels in Cairo city which are 18 hotels according to the (Egyptian hotels association, 2020).

2. This study is focusing on the SS with its dimensions (information, order taking, consultation, hospitality, safe keeping, exception, billing, and payment).And CBBE (brand awareness, brand image, perceived quality, and brand loyalty) as a second dependent variable.

3. The study was restricted to the all customers who benefit from the services of the 18 five-star hotels in Cairo city.

4. The survey lists were distributed and compiled in the time period starting from the beginning of November 2020 until the end of January 2021.

\section{Research Population}

The research population consists of the (18) five star hotels in Cairo city. The population of the study consisted of all customers who benefit from the services of these (18) five star hotels in Cairo city.

Hence, the research population was represented in all Customers who benefit from the services of the five-star hotels in Cairo, and due to the large size of the community and the difficulty of accessing all its components, in addition to the time and cost constraints, it was decided to rely on the sampling method (conveniences method) Data were collected from the sample by directing an online survey list.

\section{Research Sample}

the researcher relied on the sample method due to the difficulty of applying the comprehensive inventory method due to the large and enormous research population and time and cost constraint, and because the research here have a very large population size so the researcher used the following equation to determine the sample size (Smith, 2013).

$$
\mathrm{n}=\frac{\mathbf{Z}^{2} \mathbf{p}(\mathbf{1}-\mathbf{p})}{\mathbf{e}^{2}}
$$

(n) The sample size, (z) the confidence interval which $=1.96$ in confidence level 95\%, (p) Standard of Deviation=.5, (e) margin of error= 0.05

By substituting in the previous equation, we find that:

$$
\mathrm{n}=\frac{(1.96)^{2} .0 .5(1-0.5)}{(0.05)^{2}}=384 \text { respondents }
$$

\section{Research Variables \\ 1. Independent Variable}

المجلة العلمية للاراسات والبحوث المالية والإدارية المجلد التاسع العدد الأول يونيه 2021 - 580 - 
Supplementary Services will be measured through eight-dimensions 42-item scale adapted based on (Lovelock, 1992, 1995), to measure the level of providing SS to respondents.

\section{Dependent Variables}

Customer Based-brand Equity will be measured through fourdimensions, 34-item scale adapted based on both (Kim \& Kim, 2005), (Sean Hyun, \& Kim, 2011) to measure the level of CBBE with the surveyed in its four dimensions.

\section{Demographic Variables}

Demographic variables are measured for customers who visiting the five star hotels in Cairo city using two direct questions related to the following (gender, marital status).

\section{Theoretical Framework}

\subsection{Supplementary Services Concept}

SS can be classified into eight groups: information, order taking, consulting, hospitality, safekeeping, exceptions, billing, and payment (Lovelock et al., 2011).

SS are bolstering the core products and ought to be accessible for the customer to utilize the services/ products (Kotler\& et al, 2017).

SS can be characterized into two kinds of services. They are enhancing products or services from one perspective and facilitating services on the other. The primary sort of services is extra products or services that empower the organization to recognize its products from rivals. The second sort of service is products or services that encourage the utilization of fundamental services and enhance their attractiveness and worth (Kotler et al., 2017).

Information, order-taking, billing, and payment are all component that can facilitate the SS. These components are required for the service conveyance and help in the utilization of the core product (Lovelock \& Chew, 2009).

\subsection{Supplementary Services Dimensions}

Supplementary services surround the core product and Includes 8 service areas that fall under two main types of SS, they are facilitating supplementary services: They are needed to facilitate the receipt of the service or assists in the use of the core product, Including four subservices: information, Orders taking, billing, payment. Enhancing SS: Which brings additional value to the customer, and includes four other subsidiary services are: Consultation, hospitality, Safekeeping, exceptions (Lovelock \& Wirtz, 2007).

\subsubsection{Information}

information is an extra service that customers need to give services , to acquire full an incentive from any good or service, clients need

المجلة العلمية للاراسات والبحوث المالية والإدارية المجلد التاسع العدد الأول يونيه 2021 - 581 - 
pertinent data .New clients and possibilities are particularly ravenous for data. Information gives direction and comprehension to utilize the right coring these incorporate states of sale and use, alerts, updates, and notice of changes (Lovelock \& Wirtz, 2016)

\subsubsection{Order Taking}

The Customer may need to be informed around what may be an accessible and secure commitment to the conveyance. It is important to form the method smooth and quick. The company's order-taking ought to moreover be precise, quick and polite to empower the customer to persevere with pointless physical or mental effort and not to squander time (Lovelock, et al, 2009).

\subsubsection{Billing}

Billing is a typical supplemental service in all service. customer as a rule anticipate that bills should be clear. Mistaken, messy, or inadequate bills hazard frustrating clients who may, up to that point, have been very happy with their experience. If the customers are as of now disappointed the billing slip-up may make them much angrier. Billing ought to likewise be auspicious, in light of the fact that it urges individuals to make installment quicker. Procedures extend from verbal explanations to a machine-showed cost, and from written by hand solicitations to expound month to month articulations of record account activity and charges. Maybe the most straightforward methodology is self-billing (Lovelock \& Wirtz, 2016).

\subsubsection{Payment}

Payment/invoicing are a facilitating supplementary service that's required by customers for service transport. Customers have to be known what they pay for, how to pay and when they have to be paid. This may be facilitated by clear, correct and on-time receipt. The Customer can pay more cheerfully and faster on the off chance that a company makes the exchange more accommodating and direct for them. Outlines of components join automation deduction,, coordinate to payee or self-service installment, insert card, entering credit card number direct online to go between or payee, electronic stores trade, cash or token into a machine, modify giving or cash managing with, and improvement of voucher automation determinations from money related to the stores (Lovelock, et al., 2009).

\subsubsection{Consultation}

Consultation involves a dialog to probe customer requirements and then develop a solution that is suited to the needs of the customer. At its simplest level, consultation consists of immediate advice from a knowledgeable service person in response to the request, "What do you suggest?" .Consulting tailored to customer needs adds value to the services and goods offered by the company (Nafei,2018).

\subsubsection{Hospitality}

In an ideal world, hospitality-related services should represent happiness in meeting new customers and welcoming returning ones. Well-managed companies

المجلة العلمية للاراسات والبحوث المالية والإدارية المجلد التاسع العدد الأول يونيه 2021 - 582 - 
strive to ensure that their workers accept customers as clients, at least in small ways. Both face-to-face and telephone interactions include courtesy and consideration for customers' needs (Lovelock \& Wirtz, 2016).

\subsubsection{Safekeeping}

Safekeeping provides services by adding value to the products or services of the organization. The organization must take care of the client's personal property. SK services include the care of goods purchased by customers and the care of customers' property for goods purchased. Some customers may choose not to go to certain places that do not have safekeeping services like a safe and convenient car park. On-site safekeeping services includes coatrooms; baggage transport, handling and storage; safekeeping of valuables; and even child care and pet care (Lovelock \& Wirtz, 2016).

\subsubsection{Exceptions}

Additional services that are not supported as part of the regular service delivery are considered exceptions. Special requests, such as children's needs, dietary restrictions, medical or disability needs, are examples of elements. Warranties and promises are examples of religious observances and problem-solving., assisting customers who have been in an accident or have a medical emergency and service failures (Lovelock \& Wirtz, 2016).

\subsection{Customer-Based Brand Equity Concept}

$\mathrm{CBBE}$ is inherently associated with performance metrics such as customer loyalty, customer satisfaction and improved financial performance (Budac \& Baltador, 2013).

CBBE is described as "a collection of customer expectations, attitudes, awareness, and behaviors... that enables a brand to gain more volume or higher margins than it could without the brand name" (Christodoulides \& de Chernatony, 2010).

According to CBBE, the brand's combined loyalty, reputation, and financial benefit over time (Baker, 2007).

"Actual and/or perceived benefits and liabilities that are associated with a position and distinguish it from others" is what CBBE stands for (Papadopoulos, 2004).

\subsection{CBBE Dimensions}

Collectively, brand equity consists of four dimensions: brand awareness, brand image, perceived quality of brand, and brand loyalty, as proposed by Aaker $(1991,1996)$ and Keller (1993).

\subsubsection{Brand Awareness}

المجلة العلمية للاراسات والبحوث المالية والإدارية المجلد التاسع العدد الأول يونيه 2021 - 583 - 
Brand awareness is consciousness about the firm to the customer. It enhances the potential customer's ability to associate with a certain company's product or service (Langaro et al., 2018).

Brand awareness recognizes the availability and existence of a company's product or service, and it is important to differentiate similar products or services from competitors. Brand awareness consists of brand recognition and brand recall performance. Brand recognition relates to customers' ability to confirm prior exposure to the brand when given the brand as a cue (Romaniuk et al., 2017).

Brand awareness is the extent to which customers are familiar with the qualities or image of a particular brand of goods or services (Malik et al., 2013).

Brand awareness, brand association, perceived quality and brand loyalty have a significant impact on consumers' intention to purchase products (Jalilvand, et al., 2011).

\subsubsection{Brand Image}

Brand image defined as consumer thoughts and preferences for a brand, as reflected by the various types of brand associations held in consumers' memory. He expressed brand image as a perception or association consumers form as a result of their memory concerning a product (Keller, 2008).

Brand image is considered to be the perceptions attached by consumers to specific brands, based on reasoned and emotional perceptions (Keller, 2003).

Brand image is one of the first steps in building brand loyalty. In many cases, customers' brand preference and loyalty are solely linked to brand image (Schiffman and Kanuk 1991).

\subsubsection{Perceived Quality}

Perceived quality is the consumer's judgment about a product's overall excellence or superiority (Parasuraman, 1988). It therefore is based on consumers' or users' not managers' or experts subjective evaluations of product quality.

Perceived quality described as the process of perceived the high quality of brand in comparison with other brand in the same category (Low \& Lamb, 2000).

Perceived quality refers to the customer's perception of the superiority of a brand relative to its intended purpose and alternative brands (Hsu, et al., 2012).

\subsubsection{Brand Loyalty}

The last component of the CBBE model is the brand loyalty of the customer (Aaker 1996).

المجلة العلمية للاراسات والبحوث المالية والإدارية المجلد التاسع العدد الأول يونيه 2021 - 584 - 
Brand loyalty has been an important factor for quite a while in marketing structure of the organizations. Organizations tend to achieve brand loyalty through employing different strategies and by engaging customers to a sense of belongingness among them regarding the brand. Firms use a simple paper and pencil instrument to measure brand equity (Mahmood et al., 2018).

Based on the research variables that have been shown, the researcher will then display a model showing the relationships between these variables.

Figure (1)

The Proposed Model

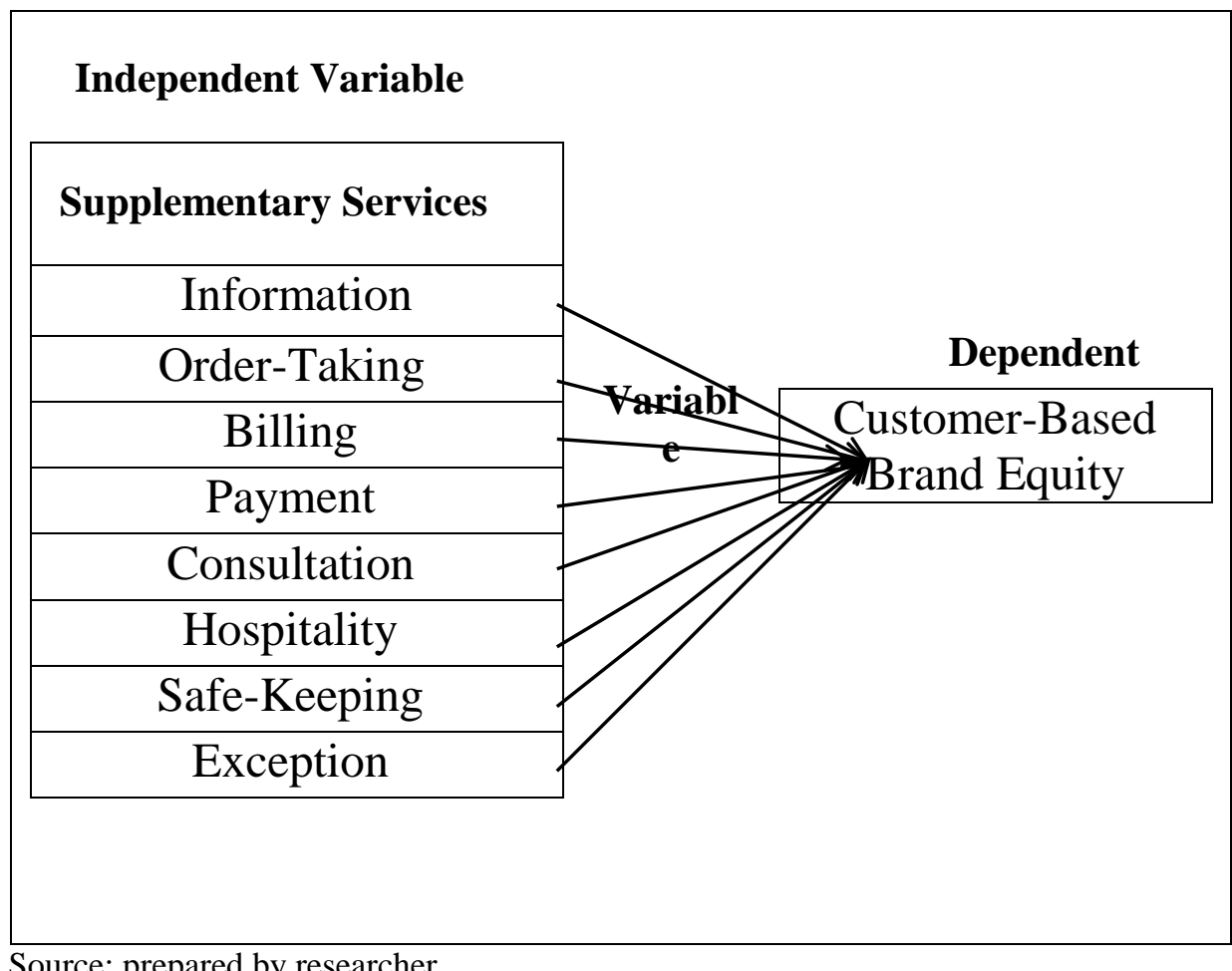

Source: prepared by researcher

\section{The Statistical Techniques of Analyzing Data and Testing Hypotheses}

13.1. The Statistical Techniques

The appropriate statistical methods were chosen for the current study includes:

1. Confirmatory Factor Analysis: was used for the purpose of validity of the measures for the different groups of variables used in the research, represented by: SS (as an independent variable) and CBBE (as dependent variables) by testing the hypotheses related to the presence or absence of a relationship between the variables and the underlying factors.

المجلة العلمية للاراسات والبحوث المالية والإدارية المجلد التاسع العدد الأول يونيه 2021 - 585 - 
2. Alpha Correlation Coefficient (ACC): was used for the purpose of verifying the degree of stability and confidence in the multi-content measures of the variables of the current study

3. Multiple Regression Analysis (MRA): used to determine the strength of the influence of the independent variable (SS) on the dependent variable (CBBE).

4. Correlation Matrix: was used as a measure of the strength of the relationship between the dependent variable (CBBE) and the independent variable (dimensions of SS).

\subsection{Techniques of testing hypotheses}

The researcher using tests such as (F-Test, T-Test) to test the first hypothesis of the current study, and the T-Test is considered one of the statistical methods that are used to compare two independent samples; therefore it was used to compare the gender in terms of male and female. The F-Test is also considered one of the statistical methods used to compare three or more independent samples, and the F-Test was used at a significance level of 5\%, and the following are the results of the T-Test for gender, and the F-Test for the effect of (gender, marital status) in the dimensions of SS.

\section{Evaluate the Reliability and Validity}

\subsection{Reliability Assessment of the SS}

The table (1) shows the degree of internal consistency of the SS as follows:

Table (1)

Outputs of the Reliability Analysis for SS

\begin{tabular}{|c|c|c|c|}
\hline $\mathbf{N}$ & SS Components & No. of statements & Alpha Coefficient \\
\hline 1 & Information & 7 & $\mathbf{7 . 7 2 2}$ \\
\hline 2 & Order Taking & 6 & $\mathbf{6 . 7 9 6}$ \\
\hline 3 & Billing & 4 & $\mathbf{0 . 6 0 4}$ \\
\hline 4 & Payment & 4 & $\mathbf{0 . 6 6 0}$ \\
\hline 5 & Consultation & 5 & $\mathbf{0 . 7 4 0}$ \\
\hline 6 & Hospitality & 5 & $\mathbf{0 . 7 6 1}$ \\
\hline 7 & Safe Keeping & 5 & $\mathbf{0 . 7 8 9}$ \\
\hline 8 & Exception & 6 & $\mathbf{0 . 7 6 3}$ \\
\hline & Total & 42 & $\mathbf{0 . 9 4 1}$ \\
\hline
\end{tabular}

Source: prepared by the researcher according to the results of statistical analysis

Alpha Correlation Coefficient (ACC) was applied on SS scale in total manner for the entire scale and each dimension of its related eight dimensions

(information, order taking, billing, payment, consultation, hospitality, safe keeping and exceptions) separately. According to table (1), the results of reliability analysis revealed that ACC for all items within each dimension of SS were above 0.60. In addition, alpha coefficient for the entire scale was about 0.94 , which exceeds the acceptable level of reliability in social sciences and represents an indication of a very high degree of reliability.

المجلة العلمية للاراسات والبحوث المالية والإدارية المجلد التاسع العدد الأول يونيه 2021 - 586 - 


\subsection{Reliability Assessment of the CBBE}

The table (2) shows the degree of internal consistency of the CBBE as follows:

Table (2)

Outputs of the Reliability Analysis for CBBE

\begin{tabular}{|c|c|c|c|}
\hline $\mathbf{N}$ & CL Components & No. of statements & Alpha Coefficient \\
\hline 1 & Brand Awareness & 4 & 0.876 \\
\hline 2 & Brand Image & 14 & 0.915 \\
\hline 3 & Perceived Quality & 10 & 0.912 \\
\hline 4 & Brand Loyalty & 6 & 0.849 \\
\hline & Total & 34 & $\mathbf{0 . 9 5 9}$ \\
\hline
\end{tabular}

Source: prepared by the researcher according to the results of statistical analysis

Alpha Correlation Coefficient (ACC) was also performed on CBBE scale in total manner for the entire scale and each dimension of its related four dimensions separately. The results of reliability analysis revealed that ACC for all items within each dimension of CBBE were above 0.60 (see table 2). In addition, alpha coefficient for the entire scale was about 0.96 , which exceeds the acceptable level of reliability in social sciences and represents an indication of a very high degree of reliability.

\section{Descriptive analysis of the study variables}

\subsection{Distribution of the Sample Items According to Demographic Variables}

The researcher has analyzed the data contained in the questionnaires which related to the demographic characteristics through calculating frequencies and percentages. This in order to describing the population items under investigation in terms of their personal and demographic characteristics (gender, marital status). The table (3) illustrates distribution of the sample items according to demographic variables. Table (3)

Distribution of the sample items according to demographic variables

\begin{tabular}{|c|l|c|c|}
\hline Variables & \multicolumn{1}{|c|}{ Category } & Frequency & Percent \% \\
\hline \multirow{3}{*}{ Gender } & Female & 167 & $56 \%$ \\
\cline { 2 - 4 } Total & Male & 133 & $44 \%$ \\
\hline \multirow{2}{*}{$\begin{array}{l}\text { Marital } \\
\text { Statues }\end{array}$} & Single & $\mathbf{3 0 0}$ & $\mathbf{1 0 0 \%}$ \\
\cline { 2 - 4 } & Married & 86 & $29 \%$ \\
\cline { 2 - 4 } & (Divorced - widower) & 183 & $61 \%$ \\
\hline \multicolumn{2}{|l}{ Total } & 31 & $10 \%$ \\
\hline
\end{tabular}

Source: Results of statistical analysis

15.2. The Descriptive Analysis of SS

This part discusses the results of the statistical analysis, related to determining the level of SS (information, order taking, billing, payment, consultation, hospitality, safe keeping and exception) in the five-star hotels in Cairo. To achieve this, the researcher evaluated the level of SS by answering the dimensions of SS, which include (42) phrases that cover the eight dimensions of SS and a presentation for each dimension separately, as shown as follows:

المجلة العلمية للاراسات والبحوث المالية والإدارية المجلد التاسع العدد الأول يونيه 2021 - 587 - 
Table (4)

The Mean and Standard Deviation for SS

\begin{tabular}{|c|c|c|c|}
\hline $\mathbf{N}$ & statements & $\begin{array}{c}\text { Mea } \\
\mathbf{n}\end{array}$ & $\begin{array}{l}\text { standard } \\
\text { deviation }\end{array}$ \\
\hline 1 & $\begin{array}{l}\text { Information of the hotel can be reached through the } \\
\text { leaflets, websites and the front desk. }\end{array}$ & 3.97 & 0.827 \\
\hline 2 & $\begin{array}{l}\text { The hotel website is satisfactory and contains all the } \\
\text { needed information. }\end{array}$ & 3.69 & 0.834 \\
\hline 3 & $\begin{array}{l}\text { Staff of the hotel always gives necessary information to } \\
\text { all customers. }\end{array}$ & 3.74 & 0.970 \\
\hline 4 & $\begin{array}{l}\text { There are many informative boards on the walls of the } \\
\text { hotel. }\end{array}$ & 3.57 & 1.008 \\
\hline 5 & $\begin{array}{l}\text { Employees are always ready to give information to } \\
\text { customers. }\end{array}$ & 3.98 & 0.894 \\
\hline 6 & The hotel operators give information through the phone. & 3.78 & 0.833 \\
\hline 7 & $\begin{array}{l}\text { There is a representative from the hotel who escorts } \\
\text { customers to clarify the hotel services for them. }\end{array}$ & 3.51 & 1.099 \\
\hline \multicolumn{2}{|r|}{ Information } & 3.75 & 0.568 \\
\hline 8 & Receptionists are always ready to help. & 3.99 & .838 \\
\hline 9 & $\begin{array}{l}\text { The receptionist of the hotel takes the customers' } \\
\text { information as soon as they check-in. }\end{array}$ & 4.00 & .927 \\
\hline 10 & $\begin{array}{l}\text { Hotel employees accurately record all customer } \\
\text { information. }\end{array}$ & 4.06 & .903 \\
\hline 11 & The receptionist answers all morning and night calls. & 3.83 & .946 \\
\hline 12 & The employees in the hotel are always ready to help. & 3.94 & .812 \\
\hline 13 & $\begin{array}{l}\text { The hotel room service is always ready to do the tasks } \\
\text { assigned to them. }\end{array}$ & 3.91 & .902 \\
\hline \multicolumn{2}{|r|}{ Order Taking } & 3.955 & .625 \\
\hline 14 & $\begin{array}{l}\text { The hotel issues the bill once the customers have checked } \\
\text { out. }\end{array}$ & 3.98 & .927 \\
\hline 15 & $\begin{array}{l}\text { There are detailed reports of the accounts of customers } \\
\text { periodically. }\end{array}$ & 3.67 & .957 \\
\hline 16 & $\begin{array}{l}\text { There is possibility of determining the amounts due on } \\
\text { the customer electronically or automatically. }\end{array}$ & 3.75 & 1.045 \\
\hline 17 & $\begin{array}{l}\text { There is possibility of issuing customer bills itself } \\
\text { electronically or automatically. }\end{array}$ & 3.19 & 1.205 \\
\hline \multicolumn{2}{|r|}{ Billing } & 3.64 & .702 \\
\hline
\end{tabular}

المجلة العلمية للاراسات والبحوث المالية والإدارية المجلد التاسع العدد الأول يونيه 2021 - 588 - 
Table (4) continued

\begin{tabular}{|c|c|c|c|}
\hline $\mathbf{N}$ & statements & Mean & $\begin{array}{l}\text { standard } \\
\text { deviation }\end{array}$ \\
\hline 18 & $\begin{array}{l}\text { The hotel accepts credit cards services or checks for } \\
\text { payment. }\end{array}$ & 3.96 & .932 \\
\hline 19 & $\begin{array}{l}\text { The customer pays the account by automatically } \\
\text { depositing the amounts in the hotel account. }\end{array}$ & 3.82 & .966 \\
\hline 20 & $\begin{array}{l}\text { The customer can pay the account and transfer } \\
\text { electronically or automatically }\end{array}$ & 3.66 & 1.080 \\
\hline 21 & $\begin{array}{l}\text { The hotel accepts more than one currency from } \\
\text { customers for the services provided to them }\end{array}$ & 3.98 & .856 \\
\hline \multicolumn{2}{|r|}{ Payment } & 3.80 & .634 \\
\hline 22 & Reception staff are available at the hotel 24 hours & 3.58 & .952 \\
\hline 23 & $\begin{array}{l}\text { Giving the customer advice regarding the purchase of } \\
\text { goods and services inside and outside the hotel. }\end{array}$ & 3.76 & 908 \\
\hline 24 & $\begin{array}{l}\text { Giving the consult for customers that help in solving } \\
\text { problems that encounter him in the hotel. }\end{array}$ & 4.04 & .785 \\
\hline 25 & $\begin{array}{l}\text { Provide the customer with the necessary information } \\
\text { regarding Food and flight schedules. }\end{array}$ & 3.43 & 1.109 \\
\hline 26 & $\begin{array}{l}\text { The hotel manager provides consult to customers during } \\
\text { their stay. }\end{array}$ & 4.02 & .816 \\
\hline \multicolumn{2}{|r|}{ Consultation } & 3.76 & .644 \\
\hline 27 & Hotel staff welcome customers & 3.98 & .795 \\
\hline 28 & $\begin{array}{l}\text { The hotel staff enjoys a good level of treating } \\
\text { customers. }\end{array}$ & 3.94 & .805 \\
\hline 29 & Employees give their best to help customers. & 3.83 & .894 \\
\hline 30 & $\begin{array}{l}\text { The management makes sure to give the best service to th } \\
\text { customers. }\end{array}$ & 3.72 & .874 \\
\hline 31 & $\begin{array}{l}\text { There is a good level of awareness and understanding } \\
\text { among all of the hotel staff. }\end{array}$ & 4.04 & .880 \\
\hline \multicolumn{2}{|r|}{ Hospitality } & 3.90 & .608 \\
\hline 32 & $\begin{array}{l}\text { No one is allowed to check the file of the customers } \\
\text { outside of the hotel. }\end{array}$ & 3.81 & .983 \\
\hline 33 & $\begin{array}{l}\text { Security is provided to every customer entering the } \\
\text { hotel. }\end{array}$ & 3.69 & .972 \\
\hline 34 & $\begin{array}{l}\text { Staff doesn't share any information about the } \\
\text { customers. }\end{array}$ & 3.90 & .910 \\
\hline 35 & The hotel takes full care of the customer's property. & 3.76 & .942 \\
\hline 36 & $\begin{array}{l}\text { Safety and care are provided for the children of the } \\
\text { customers in the hotel. }\end{array}$ & 3.96 & .897 \\
\hline \multicolumn{2}{|r|}{$\begin{array}{c}\text { Safe Keeping } \\
\end{array}$} & $\mathbf{3 . 8 2}$ & .692 \\
\hline 37 & $\begin{array}{l}\text { There is a high level of cleanliness and order inside the } \\
\text { hotel. }\end{array}$ & 4.10 & .769 \\
\hline 38 & Staff is always wearing the uniform of the hotel. & 3.91 & .889 \\
\hline 39 & The hotel provides private parking for customers. & 3.81 & .813 \\
\hline 40 & The hotel can provide all customers' needs. & 3.80 & .949 \\
\hline 41 & $\begin{array}{l}\text { The hotel can provide the required service like a five-star } \\
\text { hotel. }\end{array}$ & 3.28 & 1.125 \\
\hline 42 & $\begin{array}{l}\text { Customers are financially compensated in the event of } \\
\text { any damage to their properties. }\end{array}$ & 3.33 & 1.082 \\
\hline \multicolumn{2}{|r|}{$\begin{array}{c}\text { Exceptions } \\
\end{array}$} & 3.70 & .641 \\
\hline
\end{tabular}

المجلة العلمية للاراسات والبحوث المالية والإدارية المجلد التاسع العدد الأول يونيه 2021 - 589 - 
Source: prepared by the researcher according to the results of statistical analysis 15.2. The Descriptive Analysis of CBBE

This part discusses the results of the statistical related to determining the level of CBBE (brand awareness, brand image, perceived quality, and brand loyalty) in the five-star hotels in Cairo. To achieve this, the researcher evaluated the level of CBBE by answering the dimensions of CBBE, which include (34) phrases that cover four dimensions of CBBE.

Table (5)

The Mean and Standard Deviation for CBBE

\begin{tabular}{|l|l|c|c|}
\hline $\mathbf{1}$ & \multicolumn{1}{|c|}{ statements } & Mean & $\begin{array}{c}\text { standard } \\
\text { deviation }\end{array}$ \\
\hline $\mathbf{1}$ & I am aware of the hotel brand. & 3.51 & 0.973 \\
\hline $\mathbf{2}$ & $\begin{array}{l}\text { I can quickly recall the symbol or logo of the hotel } \\
\text { brand }\end{array}$ & 3.47 & 1.036 \\
\hline $\mathbf{3}$ & $\begin{array}{l}\text { Some characteristics of the hotel brand come to my mind } \\
\text { quickly. }\end{array}$ & 3.45 & 1.025 \\
\hline $\mathbf{4}$ & $\begin{array}{l}\text { I can recognize the hotel brand among other competing } \\
\text { brands. }\end{array}$ & 3.58 & 0.959 \\
\hline \multicolumn{2}{|c|}{ Brand awareness } & 3.50 & $\mathbf{0 . 8 5 2}$ \\
\hline $\mathbf{5}$ & Hotel' brand has a suitable image for hotel customers & 3.72 & .901 \\
\hline $\mathbf{6}$ & The hotel offers a high level of service. & 3.88 & .801 \\
\hline $\mathbf{7}$ & This hotel has a high value as compared to other hotels & 3.86 & .857 \\
\hline $\mathbf{8}$ & The hotel has a long history. & 3.76 & .897 \\
\hline $\mathbf{9}$ & $\begin{array}{l}\text { The hotel has a differentiated image from other hotel } \\
\text { brands. }\end{array}$ & 3.73 & .914 \\
\hline $\mathbf{1 0}$ & The hotel brand is familiar to me. & 3.70 & .916 \\
\hline $\mathbf{1 1}$ & The hotel is very comfortable. & 3.96 & .823 \\
\hline $\mathbf{1 2}$ & The hotel is not expensive, but it is reasonably priced. & 3.58 & .997 \\
\hline $\mathbf{1 3}$ & The hotel is a suitable place for high class. & 3.82 & .874 \\
\hline $\mathbf{1 4}$ & The staffs of the hotel treat customers well. & 3.93 & .853 \\
\hline $\mathbf{1 5}$ & I am very happy to stay in this hotel. & 3.91 & .870 \\
\hline $\mathbf{1 6}$ & The hotel is big and spacious. & 3.89 & .919 \\
\hline $\mathbf{1 7}$ & The hotel is quiet and restful. & 3.94 & .830 \\
\hline $\mathbf{1 8}$ & The hotel offers a unique service. & 3.94 & .869 \\
\hline & & $\mathbf{3 . 8 2}$ & $\mathbf{. 6 0 8}$ \\
\hline $\mathbf{1 9}$ & The staff treated customers as a special and valued. & 3.96 & .870 \\
\hline $\mathbf{2 0}$ & The hotel has up-to-date equipment. & 3.85 & .923 \\
\hline $\mathbf{2 1}$ & The staff has knowledge and confidence. & 3.92 & .840 \\
\hline $\mathbf{2 2}$ & $\begin{array}{l}\text { The hotel staff provides its services Within the specified } \\
\text { time frame. }\end{array}$ & 3.77 & .904 \\
\hline $\mathbf{2 3}$ & $\begin{array}{l}\text { The hotel staff handles complaints of customers } \\
\text { effectively. }\end{array}$ & 3.81 & .871 \\
\hline $\mathbf{2 4}$ & The hotel staff actively communicates with customers. & 3.83 & .836 \\
\hline $\mathbf{2 5}$ & The hotel is attractive. & 3.89 & .835 \\
\hline $\mathbf{2 6}$ & $\begin{array}{l}\text { The quality of food and beverages in the hotel is high } \\
\text { quality. }\end{array}$ & 3.83 & .847 \\
\hline
\end{tabular}

المجلة العلمية للاراسات والبحوث المالية والإدارية المجلد التاسع العدد الأول يونيه 2021 - 590 - 


\begin{tabular}{|c|l|c|c|}
\hline $\mathbf{2 7}$ & $\begin{array}{l}\text { Hotel staff provides customers' needs in a timely } \\
\text { manner. }\end{array}$ & 3.84 & .894 \\
\hline $\mathbf{2 8}$ & $\begin{array}{l}\text { The appearance of staff members (clean, neat, } \\
\text { appropriately dressed. }\end{array}$ & 3.97 & .865 \\
\hline \multicolumn{2}{|c|}{ Perceived quality } & $\mathbf{3 . 8 6}$ & $\mathbf{. 6 4 8}$ \\
\hline
\end{tabular}

Table (5) continued

The Mean and Standard Deviation for CBBE

\begin{tabular}{|c|l|c|c|}
\hline $\mathbf{N}$ & \multicolumn{1}{|c|}{ statements } & Mean & $\begin{array}{c}\text { standard } \\
\text { deviation }\end{array}$ \\
\hline $\mathbf{2 9}$ & I regularly visit this hotel. & 3.56 & 0.922 \\
\hline $\mathbf{3 0}$ & I intend to visit this hotel again. & 3.81 & 0.875 \\
\hline $\mathbf{3 1}$ & $\begin{array}{l}\text { I usually visit this hotel as my first choice compared to } \\
\text { hotels. }\end{array}$ & 3.74 & 0.892 \\
\hline $\mathbf{3 2}$ & I am satisfied with my visit to this hotel. & 3.86 & 0.836 \\
\hline $\mathbf{3 3}$ & $\begin{array}{l}\text { I would recommend this hotel to my friends and my } \\
\text { relatives. }\end{array}$ & 3.88 & 0.853 \\
\hline $\mathbf{3 4}$ & I don't intend to change the hotel. & 3.59 & 1.006 \\
\hline \multicolumn{2}{|c|}{ Brand loyalty } & $\mathbf{3 . 7 6}$ & $\mathbf{0 . 6 8 3}$ \\
\hline
\end{tabular}

Source: prepared by the researcher according to the results of statistical analysis

Brand Awareness: This

dimension was measured

through expressions (1-4) and the mean of brand awareness dimension (3.50) which is greater than the 3 was measured with a standard deviation of (0.852) This reflects that Customers are able to identify the brand of the hotel they are dealing with, between the brands of other hotels. However, they cannot quickly define the characteristics of a hotel when the brand comes to their mind.

Brand Image: This dimension was measured through expressions (5- 18) and the mean of these statements was greater than 3 and on the overall level the mean of the brand image dimension (3.82) which is greater than the 3 was measured with a standard deviation of (.608). This reflects that Customers enjoy the comfort and tranquility in the hotel, and also see that the hotel has reasonable prices and is not expensive.

Perceived Quality: This dimension was measured through expressions (19-28) and the mean of these statements was greater than 3 and on the overall level the mean of the Perceived quality dimension (3.86) which is greater than the 3 was measured with a standard deviation of (.648). This reflects customers' belief that the hotel employees provide all the services required of them on time without any delay, as well as wear appropriate clothes and look neat, tidy and clean

المجلة العلمية للاراسات والبحوث المالية والإدارية المجلد التاسع العدد الأول يونيه 2021 - 591 - 
Brand Loyalty: This dimension was measured through expressions (2934 ) and the mean of these statements was greater than 3 and on the overall level the mean of the brand loyalty dimension (3.76) which is greater than the 3 was measured with a standard deviation of $(0.683)$. This reflects the positive feeling of the customers towards the hotel, as they will recommend their friends and relatives to this hotel and they intend to visit this hotel again 
16. Relationship between SS and CBBE

16.1. Correlation Matrix

Table (6)

Correlation Matrix between SS and CBBE

\begin{tabular}{|c|c|c|c|c|c|c|c|c|c|c|c|}
\hline & $\begin{array}{l}\text { Research } \\
\text { variable }\end{array}$ & Information & $\begin{array}{c}\text { Order } \\
\text { Taking }\end{array}$ & Billing & Payment & Consultation & Hospitality & $\begin{array}{c}\text { Safe } \\
\text { Keeping }\end{array}$ & Exception & SS & CBBE \\
\hline & Information & 1 & & & & & & & & & \\
\hline & Order Taking & $.547^{* * *}$ & 1 & & & & & & & & \\
\hline & Billing & $.528^{* *}$ & $.467^{* *}$ & 1 & & & & & & & \\
\hline SS & Payment & $.565^{* *}$ & $.515^{* *}$ & $.589^{* *}$ & 1 & & & & & & \\
\hline & Consultation & $.658^{* *}$ & $.543^{* * *}$ & $.586^{* * *}$ & $.580^{* * *}$ & 1 & & & & & \\
\hline & Hospitality & $.677^{* * *}$ & $.616^{* *}$ & $.497^{* * *}$ & $.622^{* *}$ & $.714^{* * *}$ & 1 & & & & \\
\hline & Safe Keeping & $.604^{* * *}$ & $.534^{* * *}$ & $.506^{* * *}$ & $.549^{* *}$ & $.639^{* * *}$ & $.685^{* *}$ & 1 & & & \\
\hline & Exception & $.549^{* * *}$ & $.436^{* *}$ & $.469^{* *}$ & $.527^{* *}$ & $.617^{* *}$ & $.612^{* *}$ & $.615^{* *}$ & 1 & & \\
\hline & Total SS & $.802^{* * *}$ & $.733^{* * *}$ & $.741^{* * *}$ & $.781^{* * *}$ & $.843^{* * *}$ & $.852^{* * *}$ & $.815^{* * *}$ & $.763^{* * *}$ & 1 & \\
\hline & CBBE & $.553^{* *}$ & $.569^{* *}$ & $.389^{* *}$ & $.492^{* * *}$ & $.537^{* *}$ & $.573^{* *}$ & $.565^{* *}$ & $.567^{* * *}$ & $.669^{* * *}$ & 1 \\
\hline
\end{tabular}


It is clear from the matrix of correlation coefficients between SS and CBBE dimensions:

1. There is a positive significant correlation between total SS and CBBE where the value between them (.669).

2. There is a positive significant correlation between dimension information (SS) and CBBE, where the value between them (.553).

3. There is a positive significant correlation between Order taking as a dimension of SS and CBBE, where the value between them (.569).

4. There is a positive significant correlation between billing as a dimension of SS and CBBE, where the value between them (.389)

5. There is a positive significant correlation between Payment as a dimension of SS and CBBE, where the value between them (.492).

6. There is a positive significant correlation between Consultation and CBBE, where the value between them (.537).

7. There is a positive significant correlation between hospitality and CBBE, where the value between them (.573).

8. There is a positive significant correlation between Safe Keeping and CBBE, where the value between them (.565).

9. There is a positive significant correlation between Exception and CBBE, where the value between them (.567).

Based on the above, it can be said that the correlation analysis gives a preliminary indication of the extent of the impact of the dimensions of SS on CBBE.

\subsection{Multiple Regression Analysis for SS and CBBE}

This section attempts to provide an answer to the first question in this study which is related to the type of the relationship between SS as an independent variable and CBBE as a dependent variable. This is through testing the first hypothesis of this study which proposed that:

H0: "SS (information, order taking, billing, Payment, consultation, hospitality, safe keeping and exception) has no significant effect on CBBE in five star hotels in Cairo city".

H1:" SS (information, order taking, billing, payment, consultation, hospitality, safe keeping and exception) has significant effect on CBBE in five star hotels in Cairo city".

To achieve this, the researcher applied a multiple regression analysis method to verify the type and degree of this relationship between the SS of customers who benefit from the services in the five-star hotels in Cairo as an independent variable and $\mathrm{CBBE}$ as a dependent variable overall.

المجلة العلمية للاراسات والبحوث المالية والإدارية المجلد التاسع العدد الأول يونيه 2021 - 594 - 
The results of applying the (MRA) method can be illustrated as follows:

Table (7)

MRA Results for SS and CBBE

\begin{tabular}{|c|c|c|c|}
\hline $\begin{array}{c}\text { SS Dimensions } \\
\text { (The independent sub- } \\
\text { variables) }\end{array}$ & Beta & $\mathbf{R}$ & $\mathbf{R}^{2}$ \\
\hline 1. Information & $0.141^{*}$ & $0.553 * *$ & 1.106 \\
\hline 2. Order Taking & $0.269 * *$ & $0.569 * *$ & 1.138 \\
\hline 3. Billing & 0.076 & $0.389 * *$ & 0.778 \\
\hline 4. Payment & 0.073 & $0.492 * *$ & 0.984 \\
\hline 5. Consultation & 0.040 & $0.537 * *$ & 1.074 \\
\hline 6. Hospitality & 0.034 & $0.573 * *$ & 1.146 \\
\hline 7. Safe Keeping & $0.139^{*}$ & $0.565 * *$ & 1.13 \\
\hline 8. Exception & $0.238 * *$ & $0.567 * *$ & 1.134 \\
\hline $\mathbf{R}$ & \multicolumn{3}{|c|}{0.701} \\
\hline $\mathbf{R}^{2}$ & \multicolumn{3}{|c|}{0.492} \\
\hline CF- value & \multicolumn{3}{|c|}{35.230} \\
\hline Degree of Freedom & \multicolumn{3}{|c|}{$8-291$} \\
\hline IF- value & \multicolumn{3}{|c|}{1.98} \\
\hline Significant level & \multicolumn{3}{|c|}{$0.000 * *$} \\
\hline
\end{tabular}

Referring to the previous table (7), it is clear that:

1.The eight dimensions of SS (information- order taking- billing- paymentconsultation- hospitality- safe keeping- exception) represented by $49 \%$ (according to R2) of the total variation in SS in the five star hotels under research. Hence, about $51 \%$ of the variations in SS are explained by other factors.

2. The regression model demonstrated the significant effect of four subdimensions of supplementary services on customer based brand equity and these dimensions (information - order taking - safe keeping - exception).The value of - F was 35.230, which is a statistically significant level of 0.01 , which indicates the quality of the regression model, and confirms the significance of the effect of SS on CBBE in five-star hotels in Cairo. From the results of the previous analysis, it is clear that there is a positive statistically significant relationship between SS and CBBE.

It was decided to reject the null hypothesis which states that "SS has no statistically significant effect on CBBE in five star hotels in Cairo city" and accept the alternative hypothesis which states that "SS has statistically significant effect on CBBE in five star hotels in Cairo city" 


\section{Demographic Variables Analysis}

17.1. The respondents' views on the level of the dimensions of the SS according to their demographic characteristics.

In this part of the analysis, the researcher presents the answer to the second question, which states:

'Is there a significant difference between customers' opinions about SS in five star hotels in Cairo city, according to different demographic variables?"

This is done by testing the second hypothesis in the current study:

H2: "There is no significant difference between customers' opinions about SS in the five-star hotels in Cairo city, according to different demographic variables."

The researcher used parameter tests such as (F-Test, T-Test) to test the second hypothesis of the current research.

\subsubsection{Statistical Tests towards the Dimensions of SS according to Gender}

\section{Table (8)}

T-Test results toward the dimensions of SS according to Gender

\begin{tabular}{|c|c|c|c|c|c|c|}
\hline \multirow{2}{*}{ Dimensions } & \multicolumn{2}{|c|}{ Female } & \multicolumn{2}{c|}{ Male } & \multirow{2}{*}{ T } & \multirow{2}{*}{ Sig. } \\
\cline { 2 - 6 } & Mean & $\begin{array}{c}\text { Std. } \\
\text { Deviation }\end{array}$ & Mean & $\begin{array}{c}\text { Std. } \\
\text { Deviation }\end{array}$ & & \\
\hline Information & 3.76 & .542 & 3.73 & .601 & .387 & .699 \\
\hline Order Taking & 3.96 & .565 & 3.93 & .695 & .418 & .676 \\
\hline Billing & 3.67 & .643 & 3.60 & .772 & .828 & .409 \\
\hline Payment & 3.81 & .610 & 3.79 & .663 & .362 & .718 \\
\hline Consultation & 3.75 & .647 & 3.78 & .643 & .438 & .662 \\
\hline Hospitality & 3.92 & .599 & 3.87 & .619 & .745 & .457 \\
\hline Safe Keeping & 3.83 & .708 & 3.80 & .675 & .390 & .697 \\
\hline Exception & 3.73 & .637 & 3.67 & .646 & .739 & .461 \\
\hline SS & 3.80 & .490 & 3.77 & .525 & .545 & .586 \\
\hline
\end{tabular}

Source: results of statistical analysis

** Statistical significance at the level $1 \%$

* Statistical significance at the level $5 \%$

According to table (8), it is obvious that there are no significant differences in the respondents' opinions concerning the level of SS in the five star hotels under the study according to their gender, Whereas, the value of (sig.) was 0.586 which is greater than the level of significance 0.05 This means that the gender of customers in the five star hotels under the study is not a significant factor concerning the opinions towards the level of SS in these hotels. 
17.1.2. Statistical Tests towards the Dimensions of SS according to Marital Status

Table (9)

F-Test results toward the dimensions of SS according to Marital Status

\begin{tabular}{|c|c|c|c|c|c|c|c|c|}
\hline \multirow{2}{*}{ Dimensions } & \multicolumn{2}{|c|}{ Single } & \multicolumn{2}{c|}{ Married } & \multicolumn{2}{c|}{$\begin{array}{c}\text { Divorced- } \\
\text { widower) }\end{array}$} & \multirow{2}{*}{ F } & \multirow{2}{*}{ Sig. } \\
\cline { 2 - 9 } & Mean & $\begin{array}{c}\text { Std. } \\
\text { Deviation }\end{array}$ & Mean & $\begin{array}{c}\text { Std. } \\
\text { Deviation }\end{array}$ & $\begin{array}{c}\text { Mean } \\
\text { Std. } \\
\text { Deviation }\end{array}$ & \\
\hline Information & 3.75 & .557 & 3.78 & .532 & 3.50 & .740 & 3.30 & $.038^{* *}$ \\
\hline Order Taking & 3.87 & .609 & 4.03 & .587 & 3.71 & .797 & 4.66 & $.010^{* *}$ \\
\hline Billing & 3.72 & .700 & 3.63 & .690 & 3.46 & .765 & 1.57 & .208 \\
\hline Payment & 3.87 & .663 & 3.79 & .618 & 3.72 & .646 & .825 & .439 \\
\hline Consultation & 3.82 & .637 & 3.77 & .637 & 3.53 & .678 & 2.40 & .092 \\
\hline Hospitality & 3.92 & .633 & 3.91 & .589 & 3.75 & .642 & 1.00 & .367 \\
\hline $\begin{array}{c}\text { Safe } \\
\text { Keeping }\end{array}$ & 3.82 & .699 & 3.83 & .676 & 3.74 & .783 & .231 & .794 \\
\hline Exception & 3.81 & .630 & 3.68 & .635 & 3.50 & .665 & 2.93 & .054 \\
\hline SS & 3.82 & .523 & 3.80 & .483 & 3.61 & .561 & 2.14 & .119 \\
\hline
\end{tabular}

Source: results of statistical analysis $\quad * *$ Statistical significance at the level 1\% according (F-test)

* Statistical significance at the level $5 \%$ according (F-test)

According to table (9), it is obvious that there are no significant differences in the respondents' opinions concerning the level of SS in the five star hotels under the study according to their marital Status, Whereas, the value of (F) not significant at a level of statistical significance less than 0.05 This means that the marital Status of customers in the five star hotels under the study is not a significant factor concerning the opinions towards the level of SS in these hotels.

It was decided to accept the null hypothesis according to demographic variables (gender, marital status), This is after the variance analysis model showed that there was no fundamental difference at the level of statistical significance 0.05 according to the F-test in the opinions of customers towards the dimensions of SS according to the difference in their demographic characteristics.

17.2. The respondents' views on the level of the dimensions of the CBBE

According to their demographic characteristics

In this part of the analysis, the researcher presents the answer to the third question, which states:

'Is there a significant difference between customers' opinions about CBBE in five star hotels in Cairo city, according to different demographic variables?

This is done by testing the third hypothesis in the current study:

H3: "There is no significant difference between customers' opinions about $\mathrm{CBBE}$ in the five-star hotels in Cairo city, according to different demographic variables". 
17.2.1. Statistical Tests towards the Dimensions of CBBE according to Gender

To test the significance of the differences between males and females, the T-Test was performed as two independent samples accompanied by the Levin test (homogeneous test), and the results of this test are shown in the following table:

Table (10)

T-Test results toward the dimensions of CBBE according to Gender

\begin{tabular}{|c|c|c|c|c|c|c|}
\hline \multirow{2}{*}{ Dimensions } & \multicolumn{2}{|c|}{ Female } & \multicolumn{2}{c|}{ Male } & \multirow{2}{*}{ T } & \multirow{2}{*}{ Sig. } \\
\cline { 2 - 6 } & Mean & $\begin{array}{c}\text { Std. } \\
\text { Deviation }\end{array}$ & Mean & $\begin{array}{c}\text { Std. } \\
\text { Deviation }\end{array}$ & T \\
\hline $\begin{array}{c}\text { Brand } \\
\text { Awareness }\end{array}$ & 3.40 & .869 & 3.62 & .818 & 2.199 & $.029 *$ \\
\hline Brand Image & 3.76 & .621 & 3.90 & .583 & 1.954 & $.05^{*}$ \\
\hline $\begin{array}{c}\text { Perceived } \\
\text { Quality }\end{array}$ & 3.83 & .647 & 3.90 & .649 & .862 & .389 \\
\hline Brand Loyalty & 3.71 & .682 & 3.82 & .681 & 1.372 & .171 \\
\hline CBBE & 3.68 & .585 & 3.81 & .583 & 1.942 & $.05^{*}$ \\
\hline
\end{tabular}

Source: results of statistical analysis $\quad * *$ Statistical significance at the level 1\%

* Statistical significance at the level 5\%

According to table (10), it is obvious that there are a significant differences in the respondents' opinions concerning the level of CBBE in the five star hotels under the study according to their gender, whereas, The value of $(F)$ is significant at a level of statistical significance it is equal 0.05 This means that the gender of customers in the five star hotels under the study is a significant factor concerning the opinions towards the level of CBBE in these hotels.

17.2.2. Statistical Tests towards the Dimensions of $\mathrm{CBBE}$ according to Marital Status.

Table (11)

F-Test results toward the dimensions of CBBE according to Marital Status

\begin{tabular}{|c|c|c|c|c|c|c|c|c|}
\hline \multirow{2}{*}{ Dimensions } & \multicolumn{2}{|c|}{ Single } & \multicolumn{2}{c|}{ Married } & \multicolumn{2}{c|}{$\begin{array}{c}\text { (Divorced- } \\
\text { widower) }\end{array}$} & \multirow{2}{*}{ F } & \multirow{2}{*}{ Sig. } \\
\cline { 2 - 8 } & Mean & $\begin{array}{c}\text { Std. } \\
\text { Deviation }\end{array}$ & Mean & $\begin{array}{c}\text { Std. } \\
\text { Deviation }\end{array}$ & Mean & $\begin{array}{c}\text { Std. } \\
\text { Deviation }\end{array}$ & & \\
\hline $\begin{array}{c}\text { Brand } \\
\text { Awareness }\end{array}$ & 3.52 & .824 & 3.56 & .827 & 3.07 & .972 & 4.569 & $.010 *$ \\
\hline $\begin{array}{c}\text { Brand } \\
\text { Image }\end{array}$ & 3.83 & .610 & 3.87 & .617 & 3.55 & .470 & 3.846 & .022 \\
\hline $\begin{array}{c}\text { Perceived } \\
\text { Quality }\end{array}$ & 3.86 & .661 & 3.88 & .650 & 3.73 & .600 & .696 & .499 \\
\hline $\begin{array}{c}\text { Brand } \\
\text { Loyalty }\end{array}$ & 3.75 & .673 & 3.83 & .670 & 3.41 & .696 & 5.266 & $.006 *$ \\
\hline CBBE & 3.74 & .594 & 3.79 & .581 & 3.44 & .526 & 4.754 & $.009 *$ \\
\hline
\end{tabular}

Source: results of statistical analysis $\quad * *$ Statistical significance at the level 1\% according (F-test)

* Statistical significance at the level $5 \%$ according (F-test) 
According to table (11), it is obvious that there are significant differences in the respondents' opinions concerning the level of CBBE in the five star hotels under the study according to their marital Status, whereas, The value of $(F)$ is significant at a level of statistical significance less than 0.05 This means that the marital Status of customers in the five star hotels under the study is a significant factor concerning the opinions towards the level of CBBE in these hotels.

It was decided to reject the null hypothesis according to demographic variables (gender-marital status) and accepted the alternative hypothesis, this is after the variance analysis model showed that there was a fundamental difference at the level of statistical significance 0.05 according to the F-test in the opinions of customers towards the dimensions of CBBE according to the difference in their demographic characteristics.

\section{Research Findings}

A number of findings have been obtained. The researcher classified these findings as follows:

\subsection{Findings Related to SS}

1. The results of the descriptive analysis of SS showed, there is agreement above the average from the customer side regarding the SS with a mean (3.79).

2. There is a positive statistically significant correlation relationship between each of the eight dimensions of SS and each other dimension represented in (information, order taking, billing, payment, consultation, hospitality, safe keeping and exception).

3. There are no significant differences in the respondents' opinions concerning the level of SS in the five star hotels under the study according to their demographic characteristics, which represented in (gender, marital Status).

\subsection{Findings Related to CBBE}

1. The results of the descriptive analysis of CBBE showed that there is average agreement from the customer side regarding the CBBE with a mean (3.74).

2. There are significant differences in the respondents' opinions concerning the level of CBBE in the five star hotels under the study according to their demographic characteristics, which represented in (gender, marital status).

\subsection{Findings Related to SS and CBBE}

1. There is a positive significant correlation between SS as a whole and CBBE, this means that the higher the level of providing SS, the higher the customer based-brand equity in the five-star hotels under study.

2. There is a positive significant correlation between each dimension of SS (information, order taking, billing, payment, consultation, hospitality, safe keeping and exception), and CBBE.

3. The results of the multiple regression analysis (MRA) method showed that there is a positive statistically significant relationship between the dimensions of SS combined and CBBE and this relationship represented by $49 \%$ (according to R2) of the total variation in SS in the five star hotels under study.

\section{Research Recommendations}

$$
\text { المجلة العلمية للاراسات والبحوث المالية والإدارية المجلد التاسع العدد الأول يونيه } 2021 \text { - } 599 \text { - }
$$


1. The necessity of activating the information systems inside the hotels under study in pursuit of this goal officials must pay attention to collecting and analyzing information from the hotel's internal sources (information related to customers) as well as external sources of the hotel (information related to competing hotels) so that those outputs from the analysis process contribute to providing SS uniquely.

2. The need for officials in the five-star hotels under study to provide SS that are developed and easy to use, such as order-taking services, services related to payment and bills.

3. The need for officials in the five-star hotels under study to provide SS that value-enhancing services such as (hospitality consultation - exception) as the results showed that these services have a clear and tangible effect on increasing customer loyalty and enhancing the hotel brand to customers.

4. The necessity of activating training courses for employees in the five-star hotels under study, such as training on electronic programs and relationship management so that they are more capable and willing to provide SS in a correct manner.

5. Those responsible for hotels under- study should pay attention to spreading brand awareness among the customers; this could be through doing more promotions.

6. The need for attention of those responsible for the hotel's brand image, preservation of its history and reputation, and attention to everything that makes the hotel's image appropriate.

7. Officials must pay attention to the perceived quality provided to the customer by providing services quickly and easily, paying attention to the quality of food and beverages provided in the hotel, and also paying attention to appearance, cleanliness and order.

8. The need to develop and increase the supervisory role of the agencies responsible for monitoring the hotels under study, because those agencies focus on applying the standards related to (prices - operating ratio - number of rooms) represented in basic services and therefore the need to focus also on the related standards with (customer satisfaction levels - customer loyalty retention rates - hotel brand image for the customer) and other standards of SS.

\section{Suggested for Future Researches}

1. The possibility of conducting this research by applying to sectors other than the hotel sector, for example (companies, governmental and private educational institutions, the banking sector, the public sector, restaurants, the health sector and hospitals.

2. Study the relationship between supplementary services and increasing profitability.

3. Study the impact of supplementary services on customer's satisfaction.

4. Study the effect of supplementary services on competitive advantage.

المجلة العلمية للاراسات والبحوث المالية والإدارية المجلد التاسع العدد الأول يونيه 2021 - 600 - 


\section{References}

Aaker, D. (1996). Measuring brand equity across products and markets. California management review, 38(3), 102-20.

Aaker, D. A., \& Equity, M. B. (1991). Capitalizing on the Value of a Brand Name. New York, 28(1), 35-37.

Ahmed, S., and Latif, W. (2019). Assessing customer-based brand equity and brand competitiveness of an electronic company in Bangladesh. Journal of Research in Marketing, 10(1), 758-765.

Al-Hawari, M. (2011). Do online services contribute to establishing brand equity within the retail banking context?. Journal of Relationship Marketing, 10(3), 145-166.

Amin, S. (2014). Capitalism in the age of globalization: The management of contemporary society. Zed Books Ltd

Baker, B. (2007). Destination branding for small cities: The essentials for successful place branding. Destination Branding Book.

Barwise, P. (1993). Brand equity: snark or boojum?. International Journal of research in Marketing, 10(1), 93-104.

Bose, S., Pradhan, S., Bashir, M., \& Roy, S. K. (2021). Customer-Based Place Brand Equity and Tourism: A Regional Identity Perspective. Journal of Travel Research

Budac, C., and Baltador, L. (2013), the Value of Brand Equity. Economics and Finance Journal, 6, 444-448.

Chieng, Y., and Goi, C. (2018). Customer-based brand equity: A study on interrelationship among the brand equity dimension in Malaysia, Academic journal. Vol.5 (30), pp. 11856-11862

Christodoulides, G., and De Chernatony, L. (2010).Consumer-based brand equity conceptualization and measurement: a literature review, International journal of market research, 52(1), 43-66.

Datta, H., Ailawadi, K., and Van Heerde, H. (2017), how well does consumerbased brand equity align with sales-based brand equity and marketing-mix response. Journal of Marketing, 81(3), 1-20.

Dodd, S., Payne, S., Preston, N., and Walshe, C. (2020). Understanding the outcomes of supplementary support services in palliative care for older people. A scoping review and mapping exercise. Journal of pain and symptom management, 60(2), 449-459.

Hair. J., Black. W., Babin, B., Anderson. R., and Tatham, R. (2006). Multivariant Data Analysis. New Jersey: Pearson International Edition.

Harrington, R., Ottenbacher, M., and Fauser, S. (2017). QSR brand value: Marketing mix dimensions among McDonald's, KFC, Burger King, Subway

المجلة العلمية للاراسات والبحوث المالية والإدارية المجلد التاسع العدد الأول يونيه 2021601 
and Starbucks. International Journal of Contemporary Hospitality Management, 29(1), 551-570.

Hashem, T. (2018). The Flower of Service Concept and Its Influence on the Customer Satisfaction: Case Study of Jordanian Private Hospitals Sector. International Journal of Business and Management, 13(2).

Hsu, T., Hung, L. and Tang, J. (2012). An Analytical Model for Building Brand Equity in Hospitality Firms. Annals of Operations Research, 195(1), 355-378.

Im, H., Kim, S., Elliot, S., and Han, H. (2012). Conceptualizing destination brand equity dimensions from a consumer-based brand equity perspective. Journal of Travel and Tourism Marketing, 29(4), 385-403.

Jalilvand, M., Samiei, N., and Mahdavinia, S. (2011). The Effect of Brand Equity Components on Purchase Intention: An Application of Aaker's Model in the Automobile Industry. International Business and Management, Volume 2 (Issue No. 2), Page No. 149 -158.

Keller, K. (1993), "Conceptualizing, Measuring, and Managing Customerbased Brand Equity," Journal of Marketing, vol. 57, no. 1, pp. 1-22

Keller, K. (2008), Strategic Brand Management: Building, Measuring and Managing Brand Equity, 3rd ed., Pearson, Upper Saddle River, NJ

Keller, K., and Sood, S. (2003). Brand equity dilution. MIT Sloan Management Review, 45(1), 12.

Kheiry, B. (2019). The effect of marketing mix and after sales service toward brand equity. Journal of Economics, Business, and Accountancy Ventura, 22(1), 123-136.

Kim, H., and Kim, W. (2005) the relationship between brand equity and firms' performance in luxury hotels and chain restaurants. Tourism Management 26 (4): 549-60.

Kotler, P., Bowen, J., Makens, J., and Baloglu, S. (2017). Marketing for hospitality and tourism. Boston: Prentice Hall.

Kotsi, F., Pike, S., and Gottlieb, U. (2018). Consumer-based brand equity (CBBE) in the context of an international stopover destination: Perceptions of Dubai in France and Australia. Tourism Management, 69, 297-306.

Langaro, D., Rita, P., and de Fátima Salgueiro, M. (2018). Do social networking sites contribute for building brands? Evaluating the impact of users' participation on brand awareness and brand attitude. Journal of Marketing Communications, 24(2), 146-168.

Lovelock, C. \& Wirtz, J., (2016). Services marketing: People, technology, strategy. World Scientific Publishing Company.

المجلة العلمية للاراسات والبحوث المالية والإدارية المجلد التاسع العدد الأول يونيه 2021602 
Lovelock, C. (1992). Cultivating the flower of service: new ways of looking at core and supplementary services. Marketing, operations, and human Resources: Insights into services, 296-316.

Lovelock, C., (1995). Competing on service: technology and teamwork in supplementary services. Planning Review, 32-37.

Lovelock, C., Patterson, P., and Walker, R., (2007). Services marketing: an Asia-Pacific and Australian perspective.

Lovelock, C., Wirtz, J., and Chew, P., (2009). Essentials of services marketing. Prentice Hall Singapore

Low, G. and Lamb Jr., C., (2000), the measurement and dimensionality of brand associations, Journal of Product and Brand Management, 9 (6), 350368.

Mahmood, T., Qaseem, S., Ali, Q., Ali, H., Humayon, A., and Gohar, A., (2018). The Impact of Brand Identification, Brand Equity, and Brand Reputation on Brand Loyalty: Mediating Role of Brand Affect in Pakistan. Business and Management Research, 7(4), 46-52.

Malik, M., Ghafoor, M., Hafiz, K., Riaz, U., Hassan, N., Mustafa, M., and Shahbaz, S., (2013). Importance of brand awareness and brand loyalty in assessing purchase intentions of consumer. International Journal of business and social science, 4(5).

Nafei, W., (2018), the Impact of Supplementary Services on Customer Satisfaction and Customer Loyalty: A Study on Menoufia University Hospitals. Case Studies Volume 7, Issue 12.

Naipaul, S., and Parsa, H., (2000). SS as a Differentiation Strategy: An Empirical Investigation of Lovelock's Model in Tourism. Journal of Quality Assurance in Hospitality and Tourism, 1(1),67-80

Papadopoulos, N. (2004). Place branding: evolution, meaning and implications. Place Branding 1 (1): 36-49.

Parasuraman, A., Zeithaml, V., and Berry, L., (1988). SERVQUAL: A multiple-item scale for measuring consumer perceptions of service quality. 1988, 64(1), 12-40.

Romaniuk, J., Wight, S., and Faulkner, M., (2017). Brand awareness: revisiting an old metric for a new world. Journal of Product and Brand Management, 26(5), 469-476.

Rust, R., Lemon, K., and Zeithaml, V., (2004). Return on marketing: Using customer equity to focus marketing strategy. Journal of marketing, 68(1), 109-127.

Schiffman, L., and Kanuk, L., (1991). Communication and consumer behavior. Consumer Behavior, 2, 268-306.

المجلة العلمية للاراسات والبحوث المالية والإدارية المجلد التاسع العدد الأول يونيه 2021603 
Sean Hyun, S., and Kim, W., (2011). Dimensions of brand equity in the chain restaurant industry. Cornell Hospitality Quarterly, 52(4), 429-437.

Šerić, M., Gil-Saura, I., and Mikulić, J., (2017). Customer-based brand equity building: Empirical evidence from Croatian upscale hotels. Journal of Vacation Marketing, 23(2), 133-144.

Smith, S. (2013). Determining sample size: How to ensure you get the correct sample size. E-Book (c) Qualtrics Online Sample.

Sürücü, Ö., Öztürk, Y., Okumus, F., and Bilgihan, A., (2019). Brand awareness, image, physical quality and employee behavior as building blocks of customer-based brand equity: Consequences in the hotel context. Journal of Hospitality and Tourism Management, 40, 114-124.

Tarabieh, S., Ahmad, Z., and Siron, R. (2015). The synergistic impact of customer orientation and supplementary services on competitive advantage and organizational performance (pilot survey). International Review of Management and Business Research, 4(2), 484.

Veloutsou, C., Chatzipanagiotou, K., and Christodoulides, G., (2020). The consumer-based brand equity deconstruction and restoration process: Lessons from un-liked brands. Journal of Business Research, 111, 41-51.

المجلة العلمية للاراسات والبحوث المالية والإدارية المجلد التاسع العدد الأول يونيه 2021604 